\title{
The Effect Of Cooperative Learning Model Type STAD To Student Biology Learning Results Class XI SMA Negeri II Kabupaten Sorong
}

\author{
$1^{\text {st }}$ Jaharudin $^{1}, 2^{\text {nd }}$ Budi Santoso ${ }^{2}$ \\ \{jaharudin2008@gmail.com ${ }^{1}$, 92budisantoso@gmail.com ${ }^{2}$ \} \\ Universitas Pendidikan Muhammadiyah Sorong, West Papua, Indonesia ${ }^{1,2}$
}

\begin{abstract}
The purpose of this research is motivated by the lack of improvement in the quality of education is very fundamental in order to compete with existing educational institutions, so schools and elements must renew the quality of education in the teaching sector. teachers must be able to develop learning tools such as using the STAD (Student Team Achievement Division) cooperative learning model that can be applied to students, to determine the effect of the STAD type cooperative learning model on Biology learning outcomes for Class XI students of SMA N 2 Kab. Sorong The research method uses quasi experiment with one group desaing design. The population and sample of this study are Class XI students of SMA N 2 Kab. Sorong with 15 students. The average student test results for students of SMA N 2 Class Sorong District 5.655, which subsequently tested linearity of 0.044 smaller than 0.05 , then test the hypothesis using SPSS 20 program, the results of the test put out were obtained at 4.569 and the value of ttable 2, 00 this means tcount $>$ table, then Ha which states that there is an influence of STAD type cooperative learning is accepted, and Ho which states that there is no effect of STAD type cooperative learning is rejected, thus it can be concluded that there is an effect of STAD type cooperative learning on learning outcomes biology students of SMA N 2 Sorong Regency.
\end{abstract}

Keywords: Cooperative, STAD Type, Learning Outcomes

\section{Introduction}

The situation of society is always changing, ideally education is not only oriented to the past and present, but it should be a process that anticipates and discusses the future. Education should look far ahead and think about what students will face in the future. According to Buchori (in Trianto 2007), good education is education that not only prepares students for a profession or position, but to solve the problems they face in daily life organized by educational institutions.

SMA Negeri II Kabupaten Sorong Sorong Regency as one of the educational institutions that develops the task of educating the life of the nation, to further seek to harmonize its quality with other educational institutions. Although these efforts have been made, but in reality there are still many deficiencies that must be addressed. The most fundamental and very felt shortcomings in formal education (schools) today are the low absorptive capacity of students. This is evident in the learning outcomes of students who are still very poor (Trianto 2007). 
Based on the results of research analysis on the low learning outcomes of students, this is due to the learning process that is dominated by traditional learning, in traditional learning the atmosphere of the classroom tends to be teacher-centered so that students become passive. In this case, students are not taught learning strategies that can understand how to learn, think and motivate themselves. This problem is often found in teaching and learning activities in the classroom (Trianto 2007). This fact applies to all subjects.

The learning model that can be applied to overcome the biology learning conditions above is the STAD type cooperative learning model. In this study, researchers used cooperative learning type Student Team Achievement Division (STAD) with the consideration that the STAD type is the simplest type of cooperative learning and involves many students so that students who have difficulty will be helped and difficult material will be easily understood. According to Sanjaya (2008), STAD's cooperative learning model has advantages, including: a strategy that is powerful enough to improve academic achievement as well as social skills, including developing a sense of self-esteem, positive interpersonal relationships with others, developing time-management skills, and attitudes positive towards school. According to Efi (2007), the STAD type cooperative learning process has similarities, namely: the stage of apperception, the stage of concept formation and the stage of concept strengthening.

Science subjects cannot develop children's ability to think critically and systematically, because learning strategies are not used properly in every learning process in the classroom. Religious subjects, can not develop attitudes in accordance with religious norms, because the learning process is only directed so that children can master and memorize the subject matter. Language subjects are not directed at developing communication skills, because what is learned is more language as a science rather than as a communication tool (Sanjaya 2006). Learning Biology, it is very necessary appropriate learning models that can involve students optimally both intellectually and emotionally, because Biology teaching emphasizes process skills (Yusuf 2008). Therefore, it is necessary to apply a learning model that can help students to understand teaching material and improve learning outcomes.

Harjono (2006) STAD cooperative learning model in chemistry subjects is reported to be able to improve student learning outcomes. Ibrahim. The results of the study show that the cooperative learning model is superior in improving learning outcomes compared to individual or competitive learning experiences. With a research framework.

\section{Research Methodology}

This research is a quasi-experimental study, that is the design of this study does not use the control class, so it only uses the experimental class. With research design $\mathrm{X} \rightarrow \mathrm{Y}$ Note:

$\mathrm{X}=$ Independent Variable (STAD type Cooperative Learning Model)

$\mathrm{Y}=$ Bound Variable (Student Learning Outcomes of SMA N 2 Sorong Regency)

The population and sample in this study were students of Class 2 N High School District. Push 64 population and sample class XI were 15 students.

\subsection{Test for normality}

Normality test aims to determine the spread of data. The test uses the Chi Square formula, as follows: 


$$
X^{2}=\sum \frac{\left(f_{0}-f_{e}\right)^{2}}{f_{e}}
$$

Note:

$$
\begin{aligned}
& X^{2}=\text { Chi-kuadrat } \\
& f_{0}=\text { frekuensi empiris } \\
& f_{e}=\text { frekuensi teoritis }
\end{aligned}
$$

(Riduwan, 2008)

\subsection{Test for linearity}

$$
F_{T C}=\frac{S^{2}(T C)}{S_{2}(F)}
$$

Note:

$\mathrm{F}_{\mathrm{TC}}$

$S^{2}(\mathrm{TC})$

$S^{2}(E)$

$=$ Harga linieritas

$=$ Rata-rata jumlah kuadrat tuna cocok

$=$ Rata-rata jumlah kuadrat kekeliruan

\section{Research Results}

\subsection{Student Learning Outcomes Biology Learning Data Type STAD}

Student learning outcomes data for high school class 2 N Kab. Sorong by applying the STAD type cooperative model approach.

Table 1. Student learning outcome

\begin{tabular}{cc}
\hline No & $\begin{array}{c}\text { Nilai tes kemampuan siswa } \\
\text { pembelajaran tipe STAD }\end{array}$ \\
\hline 1 & 80 \\
2 & 70 \\
3 & 85 \\
4 & 70 \\
5 & 80 \\
6 & 85 \\
7 & 85 \\
8 & 80 \\
9 & 77 \\
10 & 80 \\
11 & 70 \\
12 & 83 \\
13 & 85 \\
14 & 73 \\
15 & 80 \\
\hline
\end{tabular}

\subsection{Test for normality}

Based on the normality test using the SPSS 20 program, the significance value of 0.980 is greater than 0.05 , so that it can be concluded that the data are normally distributed. 
Table 2. One-Sample Kolmogorov-Smirnov Test

\begin{tabular}{llr}
\hline & & $\begin{array}{c}\text { Unstandardized } \\
\text { Residual }\end{array}$ \\
\hline $\mathrm{N}$ & Mean & 15 \\
Normal Parameters ${ }^{\mathrm{a}, \mathrm{b}}$ & Std. Deviation & $0 \mathrm{E}-7$ \\
& Absolute & 1.91703012 \\
Most Extreme Differences & Positive & .121 \\
& Negative & .121 \\
Kolmogorov-Smirnov Z & & -.106 \\
Asymp. Sig. (2-tailed) & & .470 \\
\hline a. Test distribution is Normal. & \\
b. Calculated from data. & \\
\end{tabular}

\subsection{Linearity test}

Table 3. ANOVA Table

\begin{tabular}{|c|c|c|c|c|c|c|c|}
\hline \multicolumn{8}{|c|}{ ANOVA Table } \\
\hline & & & $\begin{array}{l}\text { Sum of } \\
\text { Squares }\end{array}$ & df & $\begin{array}{l}\text { Mean } \\
\text { Square }\end{array}$ & $\mathrm{F}$ & Sig. \\
\hline \multirow{5}{*}{$\begin{array}{l}\text { Learning Outcomes * STAD } \\
\text { Learning Mode }\end{array}$} & \multirow{3}{*}{$\begin{array}{l}\text { Between } \\
\text { Groups }\end{array}$} & (Combined) & 432.733 & 6 & 72.122 & 38.465 & .000 \\
\hline & & Linearity & 396.283 & 1 & 396.283 & 211.351 & .000 \\
\hline & & $\begin{array}{l}\text { Deviation from } \\
\text { Linearity }\end{array}$ & 36.450 & 5 & 7.290 & 3.888 & .044 \\
\hline & \multicolumn{2}{|c|}{ Within Groups } & 15.000 & 8 & 1.875 & & \\
\hline & \multicolumn{2}{|l|}{ Total } & 447.733 & 14 & & & \\
\hline
\end{tabular}

Table 4. Measure of Association

\begin{tabular}{|l|r|r|r|r|}
\hline \multicolumn{7}{|c|}{ Measures of Association } & \multicolumn{1}{|c|}{} \\
\hline Learning Outcomes * STAD Learning Model & .941 & .885 & .983 & .966 \\
\hline & & & & \\
\hline
\end{tabular}

Based on the significant value of the SPSS output, a significance value of 0.044 is less than 0.05 . Which means there is no significant linear relationship between STAD Learning Model variables $(\mathrm{X})$ to the learning outcomes variable $(\mathrm{Y})$.

\subsection{Result}

Table 5. Result

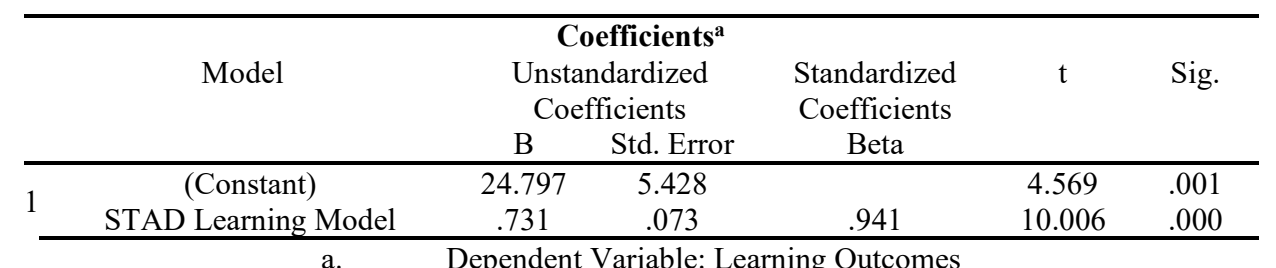

a. Dependent Variable: Learning Outcomes 
Based on the table data in the values obtained are distributed into the $\mathrm{t}$ test formula and obtained tcount 4,569 and ttable value of 2.00 this means tcount $>$ ttable, then Ha which states that there is an influence of STAD type cooperative learning is accepted, and Ho which states that there is no effect of STAD type cooperative learning being rejected, thus it can be concluded that there is an effect of type STAD cooperative learning on biology learning outcomes of SMA N 2 students in Sorong Regency.

\section{Discussion}

The results of the data analysis showed the average value of biology learning outcomes of Sorong District High School 2 students taught by the STAD type cooperative learning towards the biology learning outcomes of Sorong District N 2 High School students with a value of 4.569 and a ttable value of 2.00. This shows that there is an influence of cooperative learning on learning outcomes. STAD cooperative learning shows the responsibility given is to understand and complete a task together.

But basically the STAD type of cooperative learning can stimulate students to be actively involved in working together, discussing and helping each other between group members in learning so that they can construct their own understanding together. Although, there are still students who are still ashamed to be actively involved in learning.

In line with research conducted by several experts, one of these is in line with the results of previous studies conducted by Novia (2015) found that there are significant differences in the results of Civics learning students who take STAD type cooperative learning models assisted with multimedia learning and students who follow conventional learning with tcount $6,045>$ ttable 2,000,

Marliana (2015) found that there were significant differences in the results of science learning between students who took learning with STAD learning models and students who took learning with conventional learning models (tcount $=11.499>$ ttable $=1.665$ ),

Suardi (2014) found that there were differences in English reading learning outcomes between students who took the STAD type cooperative learning model and students who followed the conventional learning model for students who had low achievement motivation with calculations, and found that Qcount $=4.146$ and Qtable (0.05) 3.68 (Qcount $>$ Qtable).

In line with the research proposed by this is in line with the findings of research conducted by the results of this study in line with the results of research conducted by Reporters (2012) The results of the study obtained stated that learning with the STAD type cooperative model in social studies subjects was able to increase learning activities and the learning outcomes of elementary school social studies students.

Reviewing some previous research findings has proven that the STAD type cooperative learning model has a very high effectiveness for the acquisition of student learning outcomes both in terms of their influence on mastery of subject matter as well as in the development and training of attitudes and social skills that are very beneficial to students in their lives in the community. . Based on the explanation above, it can be concluded that the STAD cooperative learning model is very effective to be applied to improve student learning outcomes. Thus educators are able to develop the potential of students so that learning outcomes increase. 


\section{Conclusions}

Based on the results and discussion of the study it can be concluded, that there is an influence of the STAD type cooperative learning model on significant learning outcomes with a value of tcount $>$ ttable is $4.569>2.00$. Thus the hypothesis in this study $\mathrm{Ha}$ is acceptable and Ho is rejected, which means that there is a significant influence on the type of STAD cooperative learning on the learning outcomes of students of SMA N 2 Sorong Regency.

\section{References}

[1] Arikunto, S. Basics of Educational Evaluation. Yogyakarta: Earth Literacy, 2002.

[2] Djamarah, D, S, et al. Teaching and Learning Strategies. Jakarta: Rineka Cipta.2002.

[3] Dimyati, et al. Study and Learning. Jakarta: Rineka Copyright.2001.

[4] Hamzah B. U. Learning Planning. Gorontalo: First Literacy Earth, 2006.

[5] Hartina. "Comparison of Learning Outcomes: In Terms of Learning Style Differences in the Field of Biological Studies Class VIII Middle School 4 Tinambung District. Polman". Undergraduate Thesis, Faculty of Tarbiyah and Teacher Training, Makassar. 2009

[6] Harjono, N. "Application of the STAD Cooperative Learning Model as an Effort to Maximize the Implementation of the KBK 2004 in Chemistry Subjects in Class X of SMAN 5 Semarang" .2006.

[7] Isjoni. "Cooperative Learning". Bandung: Alfabeta.2009

[8] Purwanti, Y. "The Effectiveness of STAD and Jigsaw Cooperative Learning Implementation Type in the Main Material of Classification of Living Things in Class VII Students of NU Unggaran (Semarang State University). Available: http: /// H: //2814.html. (September 8, 2009)

[9] Rustaman, N, Y, et al. Biology Teaching Strategies. Jakarta: UPI. 2003

[10] Sarwono, J. Complete Guide to Learning Statistics Computing Using SPSS 16. Yogyakarta. Andi Offset.2009

[11] Sanjaya, Vienna. Standardized Process Education Learning Process. Jakarta: Kencana, 2006.

[12] Sharan, S. Handbook of Cooperative Learning. Yogyakarta: Imperium.2009

[13] Slameto. "Learning and Factors That Influence It" .Bandung: Rineka Cipta.2003

[14] Sudijono, A. Introduction to Educational Evaluation. Jakarta: Grafindo.2005.

[15] Sugiyono Research methods 